\title{
GIS-RUSLE Interphase Modelling of Soil Erosion Hazard and Estimation of Sediment Yield for River Nzoia Basin in Kenya
}

\section{Akali Ngaywa Moses*}

Department of Disaster Preparedness and Engineering Management (DPEM), Masinde Muliro University of Science and Technology (MMUST), Kakamega, Kenya

\begin{abstract}
River Nzoia basin is predisposed to degradation attributed to poor anthropogenic land use practices, soil erosion and sedimentation. The objective of this study was to model soil erosion hazard and estimate sediment yield for river Nzoia basin. Database of the basin comprised of $90 \mathrm{~m}$ DEM, LandSat imagery, rainfall, and soil data. Simulated RUSLE model factors (R, K, LS, and C) were multiplied using the raster calculator in ArcGIS 10.1. This generated the soil erosion hazard map for river Nzoia basin with an average annual soil loss rate of 0.51 and a maximum of $8.84 \mathrm{Mton} \mathrm{ha-1}^{-1} \mathrm{yr}^{-1}$. This translates into a mean annual soil loss of $6.579 \times 10^{5}$ Mtonyr $^{-1}$. Sediment Delivery Ratio (SDR) of 0.121 revealed that $87.9 \%$ of the soil eroded by water in the basin is deposited before reaching the basin outlet. Average annual sediment yield estimated was 0.06 Mtonyr $^{-1}$. Soil erosion modeling results showed that river Nzoia basin is experiencing varying erosion rates spatially. The interplay among the RUSLE factors strongly influence average annual soil loss rates. Areas experiencing high soil loss rates are closely linked to annual cropland, deforested and high elevation points. Low rates of soil loss are attributable to soil conservation practices and protected areas such as game parks. Thus, there is a close coupling between soil loss and land use category in river Nzoia basin. Sustainable land use practices should be embraced to support conservation programmes to mitigate soil erosion, prevent sedimentation and reduce sediment yield in the river channel.
\end{abstract}

Keywords: River Nzoia basin; Model; GIS; RUSLE; Soil erosion hazard map; Sediment yield

\section{Introduction}

Soil erosion is one of the significant environmental hazard and land degradation challenge experienced worldwide. About $80 \%$ of the world's agricultural land suffers from moderate to severe erosion [1]. Accelerated erosion due to human-induced environmental alterations is on the increase and influencing river sedimentation in many parts of the world $[2,3]$. River sedimentation depends on natural characteristics of river basins and anthropogenic land use influences in the basins [4]. Part of the sediment generated is not deposited before being transported from the basin. According to Catari [5], this is referred to as sediment yield. It is the gross erosion within a river basin. In Ethiopia, population pressure has accelerated soil erosion destroying the soil resource [6].

As argued by Kithiia and Ongwenyi [7], in Kenya, originally forested areas have presently been cultivated resulting into accelerated soil erosion rates accentuating high sedimentation of river systems. Njoro river basin has experienced increased erosion rates mainly due to unsustainable land use practices and lack of conservation measures [8]. River Nzoia contributes the most sediment loading to Lake Victoria from the Kenyan river basins $[9,10]$. The river periodically experiences channel blockage by heavy silt deposits transported from the deforested upper basin areas which contributes to flood disaster in Budalang'i flood plains [11].

Soil erosion hazard mapping and measurement provide the critical basic knowledge to assess the phenomena and formulate mitigative actions required. Erosion hazard map helps to identify erosion hot spot areas and inform planning and design of the prescribed control activities [12]. Therefore, there is need to accurately assess and map soil erosion and determine specific control activities. Its fundamental concern is to balance the use of natural resources against the need for the ecosystem protection [13].

In a study to determine the distribution of erosion in the Mfolozi drainage basin of South Africa, Watson and Ramokgopa [14] developed a map showing the location of 19 categories of potential sediment sources. This was from extensive field surveys and air photo interpretation. According to Mhangara [15], factors that interact to generate and cause soil erosion include topography, soil erodibility, rainfall erosivity, vegetation cover and conservation practices.

Soil erosion models, such as the Revised Universal Soil Loss Equation (RUSLE) [16] estimate gross soil erosion rate at plot-scale. Soil erosion and sediment delivery approaches are usually based on RUSLE and sediment delivery ratio (SDR) [17]. Sediment yield is controlled by factors that influence erosion and sediment delivery. They include; land use, soil type, local topography, climate, basin morphology, drainage network characteristics and vegetation cover [18]. This study sort to model soil erosion hazard and estimate sediment yield for river Nzoia basin. It applied Revised Universal Soil Loss Equation (RUSLE) in Geographic Information System (GIS) environment. Soil erosion hazard distribution in the basin was modelled and the mean annual soil loss rate and sediment yield estimated.

\section{Materials and Methods}

\section{Study area}

River Nzoia basin lies between latitudes $1^{\circ} 30^{\prime} \mathrm{N}$ and $0^{\circ} 05^{\prime} \mathrm{S}$ and longitudes $34^{\circ}$ and $35^{\circ} 45^{\prime} \mathrm{E}$. River Nzoia originates from Cheranganyi Hills and Mt Elgon at a mean elevation of $2300 \mathrm{~m}$ above sea level (asl) and drains into the trans-boundary Lake Victoria at an altitude of 1000

*Corresponding author: Akali Ngaywa Moses, Department of Disaste Preparedness and Engineering Management (DPEM), Masinde Muliro University of Science and Technology (MMUST), Kakamega, Kenya, Tel: 2547331200202; E-mail: nmakali4@gmail.com

Received July 19, 2017; Accepted July 26 2017; Published July 28, 2017

Citation: Moses AN (2017) GIS-RUSLE Interphase Modelling of Soil Erosion Hazard and Estimation of Sediment Yield for River Nzoia Basin in Kenya. J Remote Sensing \& GIS 6: 205. doi: 10.4172/2469-4134.1000205

Copyright: $\odot 2017$ Moses AN. This is an open-access article distributed under the terms of the Creative Commons Attribution License, which permits unrestricted use, distribution, and reproduction in any medium, provided the original author and source are credited. 
$\mathrm{m}$ asl. The River is $334 \mathrm{~km}$ long with a basin area of about $12,900 \mathrm{~km}^{2}$. Mean annual rainfall received in the basin varies from a maximum of 1100 to $2700 \mathrm{~mm}$ and a minimum of 600 to $1100 \mathrm{~mm}$ [19].

\section{Data collection}

Primary data were collected through observation and photography. Secondary datasets were categorized into four groups: hydrometeorological, soil data, land use, and topographical. Table 1 shows data types that were used and their respective sources.

\section{Data preprocessing}

Data pre-processing was undertaken using ArcGIS 10.1 and Environment for Visualizing Images (ENVI) 4.7. Spatial data sets were all converted to appropriate data formats for application in the modelling process and geo-referenced in the Universal Transverse Mercator (UTM) coordinate system (UTM zone 36N, WGS-84 ellipsoid) for compatibility with the DEM used in this study.

\section{Methods}

A 90 m resolution Digital Elevation Model (DEM) for river Nzoia basin was used to provide physical characteristics of the basin. Basin components were categorized into; rainfall, land use, slope and slope length, soil type, runoff, water erosion and sedimentation. Geographic Information system (GIS) tools were used to analyze and display spatial information. Water erosion hazard map was generated and the average annual soil loss rate estimated by the help of the Revised Universal Soil Loss Equation (RUSLE) model in GIS environment. Sediment yield was computed from sediment delivery ratio (SDR) that was determined through application of area based methods developed by Vanoni (1975), USDA (1979) and Boyce (1975). Modelling of soil erosion hazard map entailed calculation of six input Revised Universal Soil Loss Equation (RUSLE) model factors controlling soil erosion. The factors (R, K, C, and LS) were generated in form of distributed Remote Sensing (RS) and GIS data layers using ArcMap 10.1 software. In this study, p-factor was assigned a uniform weight of 1.0 (no land use influence) [20]. Methodology for generating the RUSLE model factors and estimation of the average annual soil loss rate was summarized in a schematic diagram (Figure 1).

\section{Spatial erosion hazard validation}

Classification accuracy assessment of the results was performed based on urban centres' shape file for the study area, overlay information from topographic base map and Google Earth and actual visit of randomly selected sites on the erosion hazard map.

\section{Results and Discussion}

\section{Spatial distribution of soil erosion hazard}

Spatial distribution of soil erosion hazard was modeled through overlay of the RUSLE factors and presented in form of a map.

\begin{tabular}{|c|c|}
\hline Data Type & Source \\
\hline $\begin{array}{c}\text { Digital Elevation Model (DEM) and } \\
\text { LandSat imagery }\end{array}$ & $\begin{array}{c}\text { Regional Centre for Mapping } \\
\text { of Resources for Development } \\
\text { (RCMRD) }\end{array}$ \\
\hline $\begin{array}{c}\text { Rainfall, maximum and minimum } \\
\text { temperature, relative humidity, wind } \\
\text { speed }\end{array}$ & $\begin{array}{c}\text { Kenya Meteorological Department } \\
\text { (KMD) }\end{array}$ \\
\hline River discharge and sediment Loading & $\begin{array}{c}\text { Water Resources Management } \\
\text { Authority (WARMA) }\end{array}$ \\
\hline Soil data & $\begin{array}{c}\text { Food and Agriculture organization } \\
\text { (FAO) (http://www.fao.org) }\end{array}$ \\
\hline
\end{tabular}

Table 1: Data types and sources.
Soil types in river Nzoia basin: Figure 2 shows the dominant soil types in river Nzoia basin. Figure 2 shows that the basin is covered by a wide range of soil types, they include Humic Nitisols. These are brown/ yellow clayey soils. Moderately developed Humic Cambisols are also found in the basin. Haplic Acrisols with subsurface accumulation of low activity clays and low base saturation are also evident in the basin. In addition, there are Humic Ferralsols which are deep, strongly weathered soils but physically stable sub-soils. For purposes of this study, the finer classes were reclassified broadly based on soil texture (Clayey, Loamy, Sandy and Very clayey), see Figure 3. Percentage coverage for the textual classes was computed and illustrated as shown in Figure 4.

Figure 4 indicates that clayey and loamy soils occupy $68 \%$ and $18 \%$, respectively. Clay soil is known for high specific retention of water, thus reducing infiltration of storm water while loamy soil has a moderate infiltration rate. Very clayey and sandy each account for $7 \%$ of the soil coverage in the study area. Sandy soil has poor specific water retention and thus allows water to infiltrate at a high rate. The basin can be categorized for being mainly clayey given that very clayey and clayey account for about $75 \%$ of the soil distribution in the basin. Therefore, the basin has a high specific retention of water. This attribute has the tendency to reduce soil erosion due to overland flow. As a result, it would be expected that minimal erosion is experienced in river Nzoia basin if other conditions are kept constant.

Chi-square $\chi^{2}$ test was performed to determine the level of variation in soil texture in river Nzoia basin. The calculated $\chi_{3,0.05}^{2}=101.84$ is greater than the table value.

$\chi_{3.0 \mathrm{~s}}^{2}=7.81$ This shows that the Chi-square value is significant. Therefore, there is a significant disparity in the spatial distribution of soil texture in the basin.

Other factors that may influence erosion in the basin include; deforestation and sand harvesting that enhance river bank degradation. Figure 5 shows river Nzoia channel widening due to the collapse of river bank associated with sand harvesting upstream of the bridge at Webuye.

Rainfall runoff erosivity (R) factor: The average annual $\mathrm{R}$ factor value varied from 339.39 to $855.00 \mathrm{MJ} \mathrm{mmha}^{-1} \mathrm{year}^{-1}$. More rainfall erosivity was observed in the middle basin extending towards the lower part of the basin. The upper basin covering areas such as Mount Elgon, Cherenganyi hills and Nandi escarpments which coincide with higher elevation of the study area experience low rainfall erosivity. Figure 6 shows the spatial distribution of R-factor map.

Soil erodibility $(\mathbf{K})$ factor: Soil erodibility $K$ value map was generated to show spatial distribution of erodibility ranging between 0.00 and 0.305 -ton $\mathrm{ha}^{-1} \mathrm{MJ}^{-1} \mathrm{~mm}^{-1}$, Figure 7 .

Slope and slope length (LS) factor: Slope and slope length (LS) is a composite factor whose values are used to show the effects of topography. The slope (S) and slope length (L) factors generated were combined using Equation 1 to yield the topographic factor LS, Figure 8.

$$
L S=\sqrt{\frac{l}{22}}\left(0.065+0.045 * s+0.0065 * s^{2}\right)
$$

where, $l$-Slope length $(\mathrm{m}) ; s$ - Percent slope.

Vegetation Cover (C) factor: Vegetation Cover (C) factor has an inverse relationship with NDVI. It was calculated using Equation 2.

$$
C=\exp \left(-\alpha \frac{N D V I}{\beta-N D V I}\right)
$$




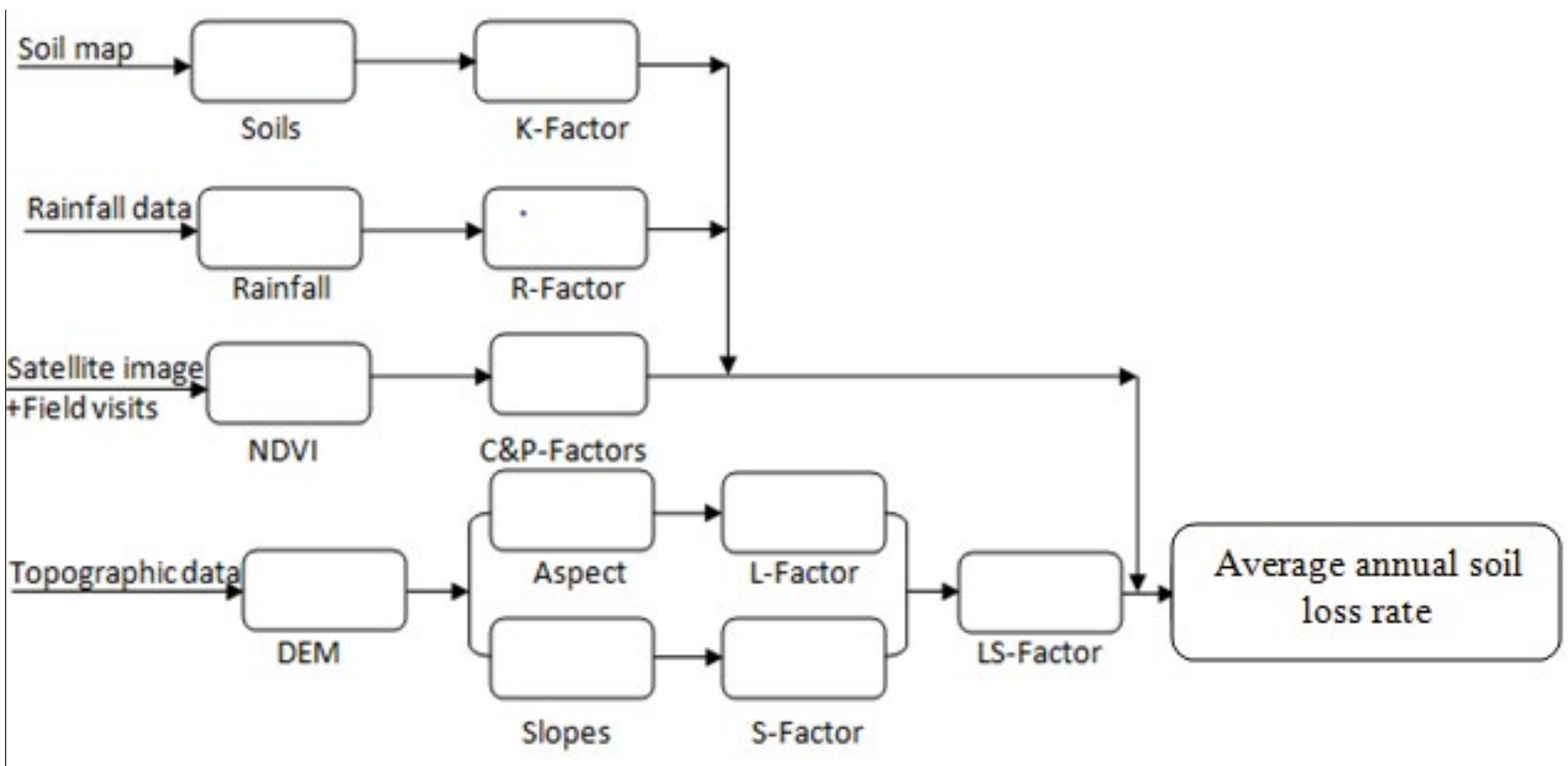

Figure 1: Methodology for generating RUSLE model factors (Adopted from Fistikoglu and Harmancioglu).

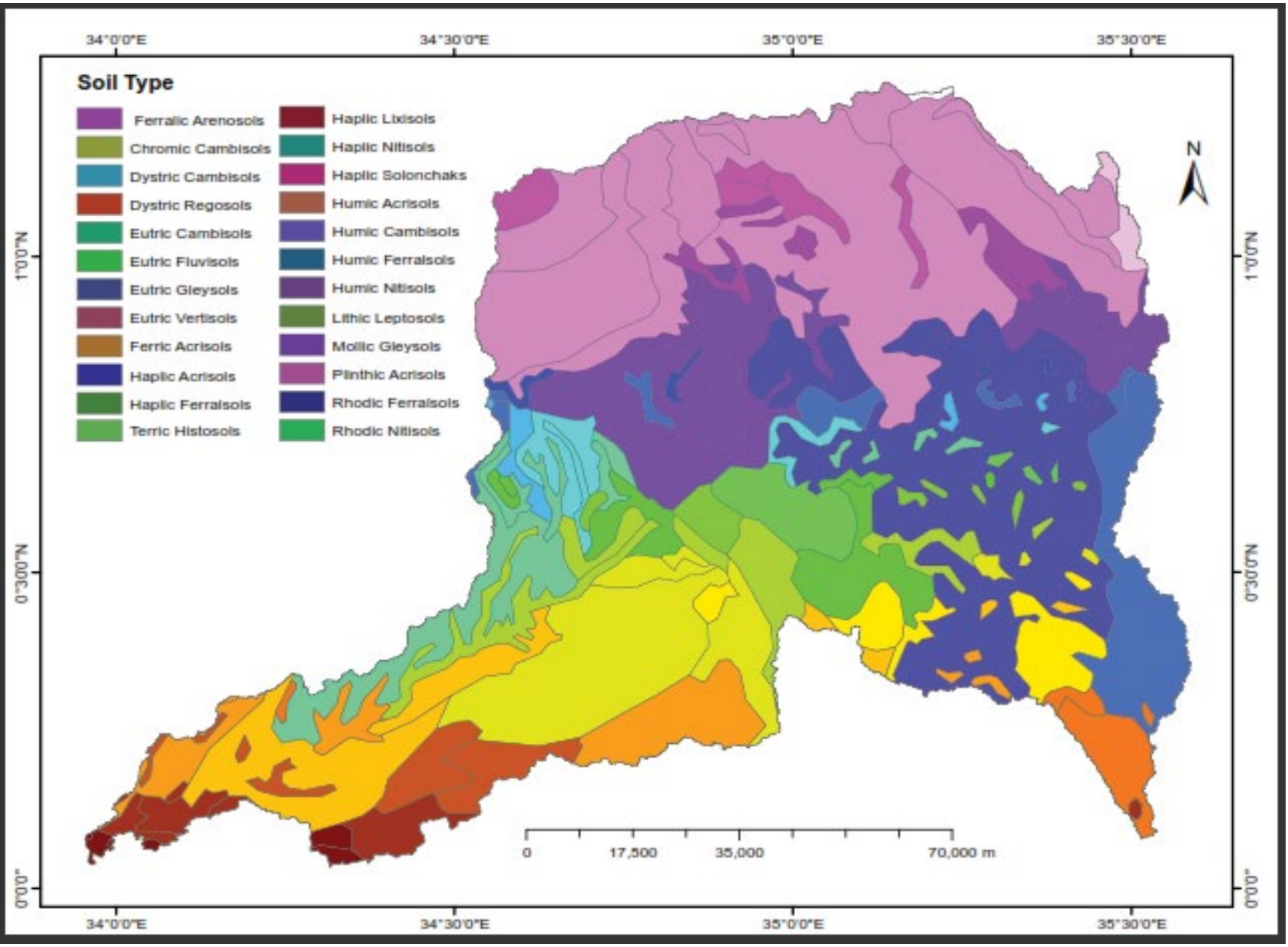

Figure 2: River Nzoia basin major soil types. 


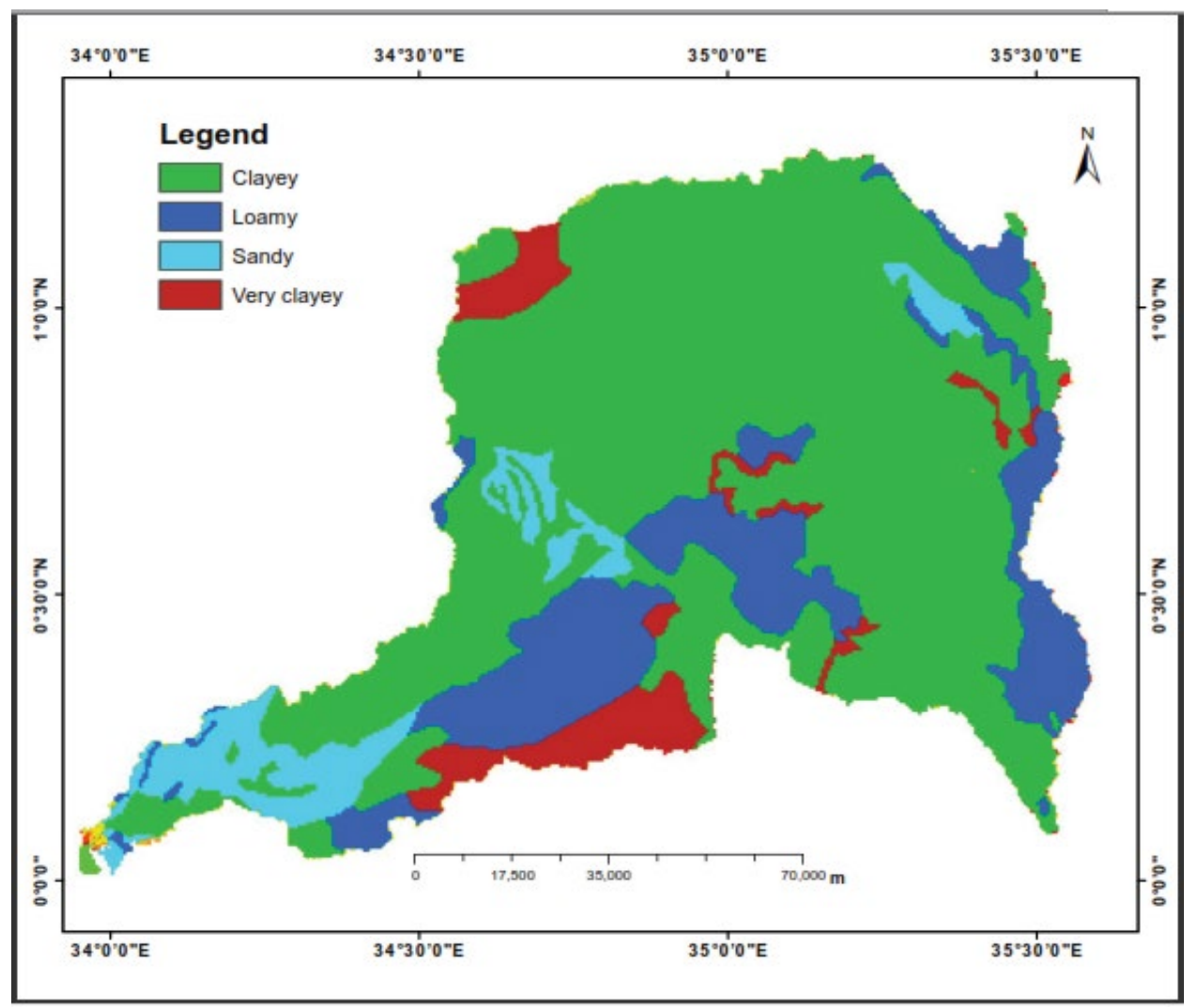

Figure 3: River Nzoia basin soil texture classification.

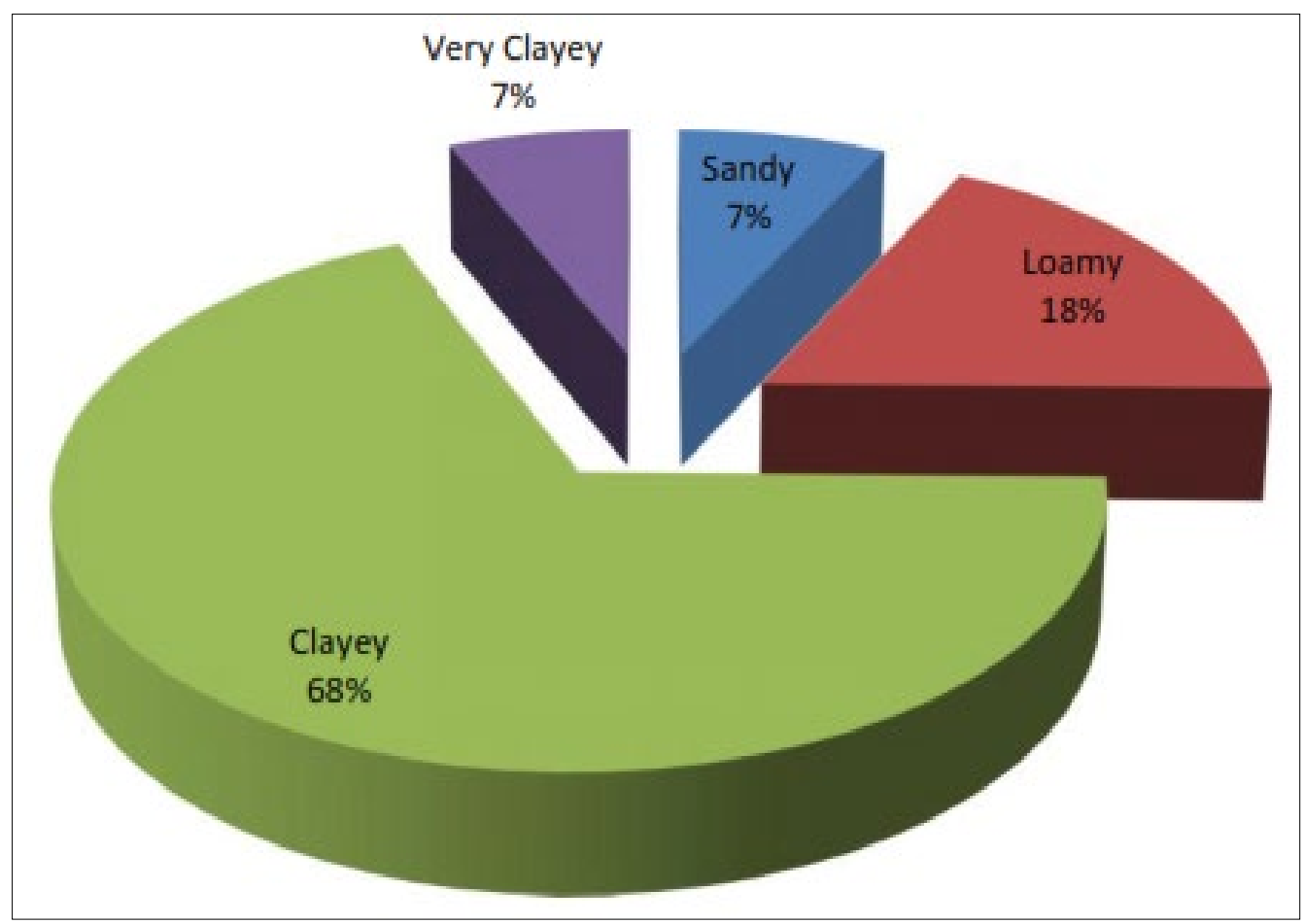

Figure 4: River Nzoia basin soil textual percentage coverage. 


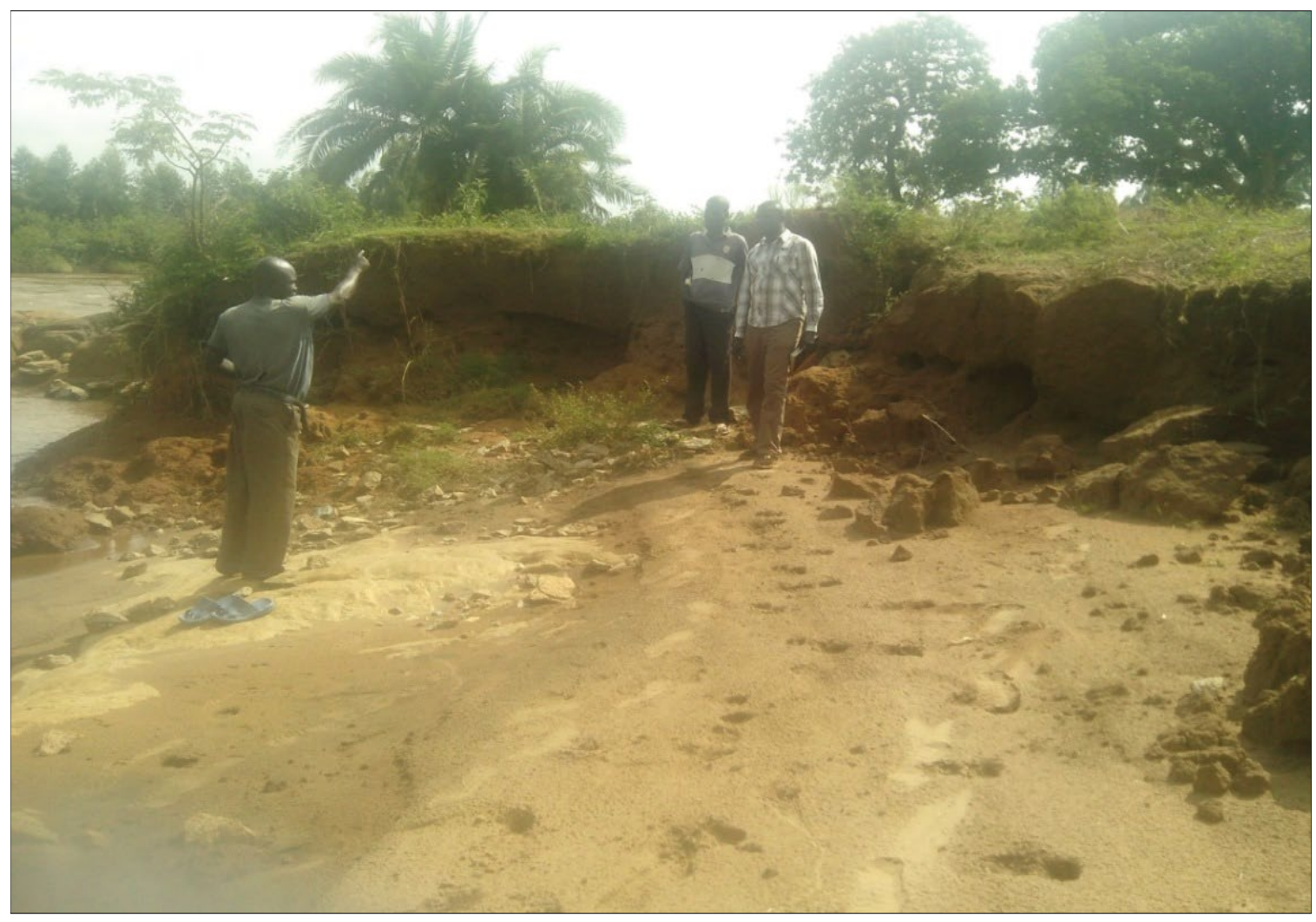

Figure 5: Eroded river bank due to sand harvesting upstream of Webuye bridge.

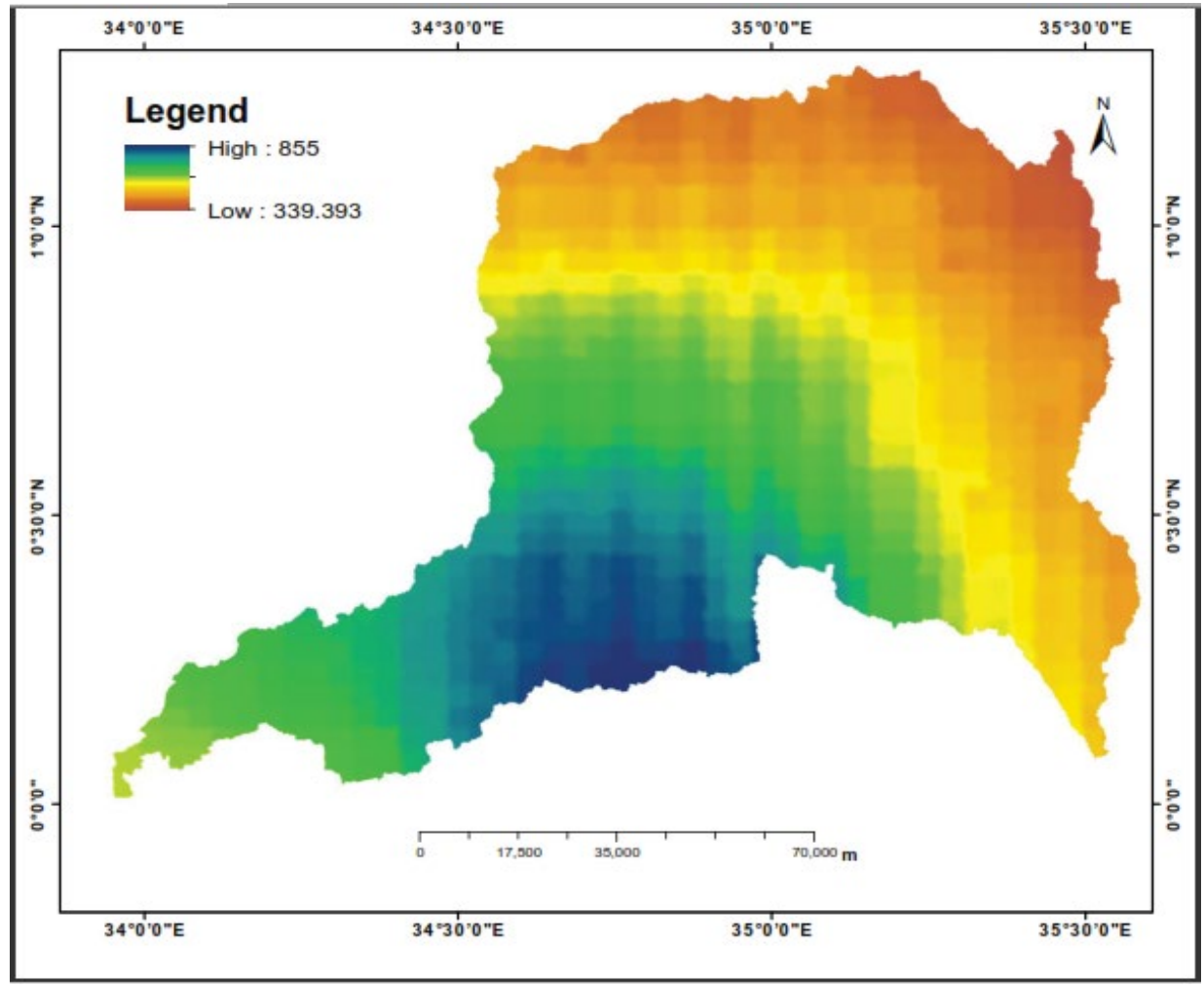

Figure 6: River Nzoia basin runoff erosivity (R) factor. 


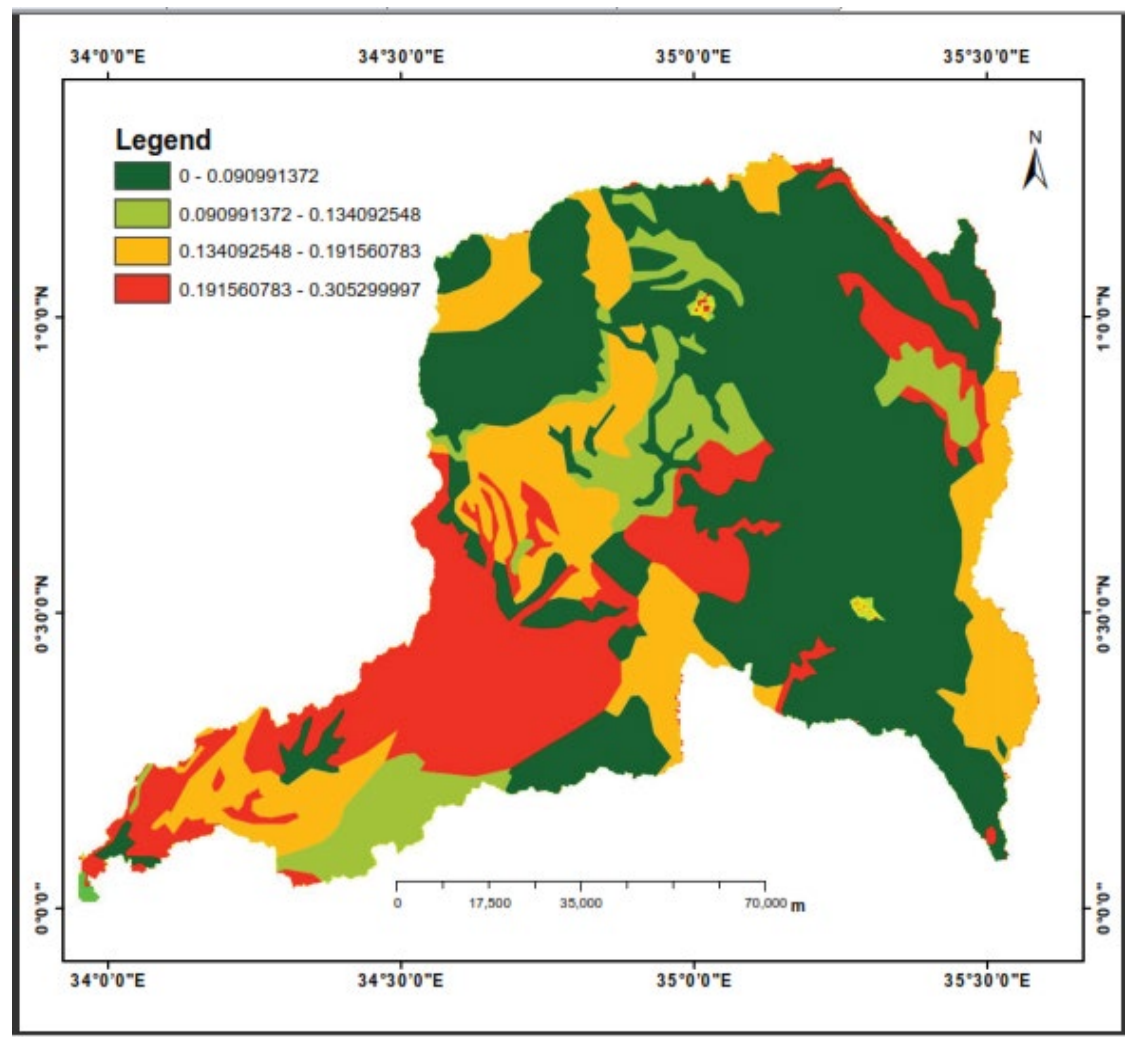

Figure 7: River Nzoia basin soil erodibility (K) factor.

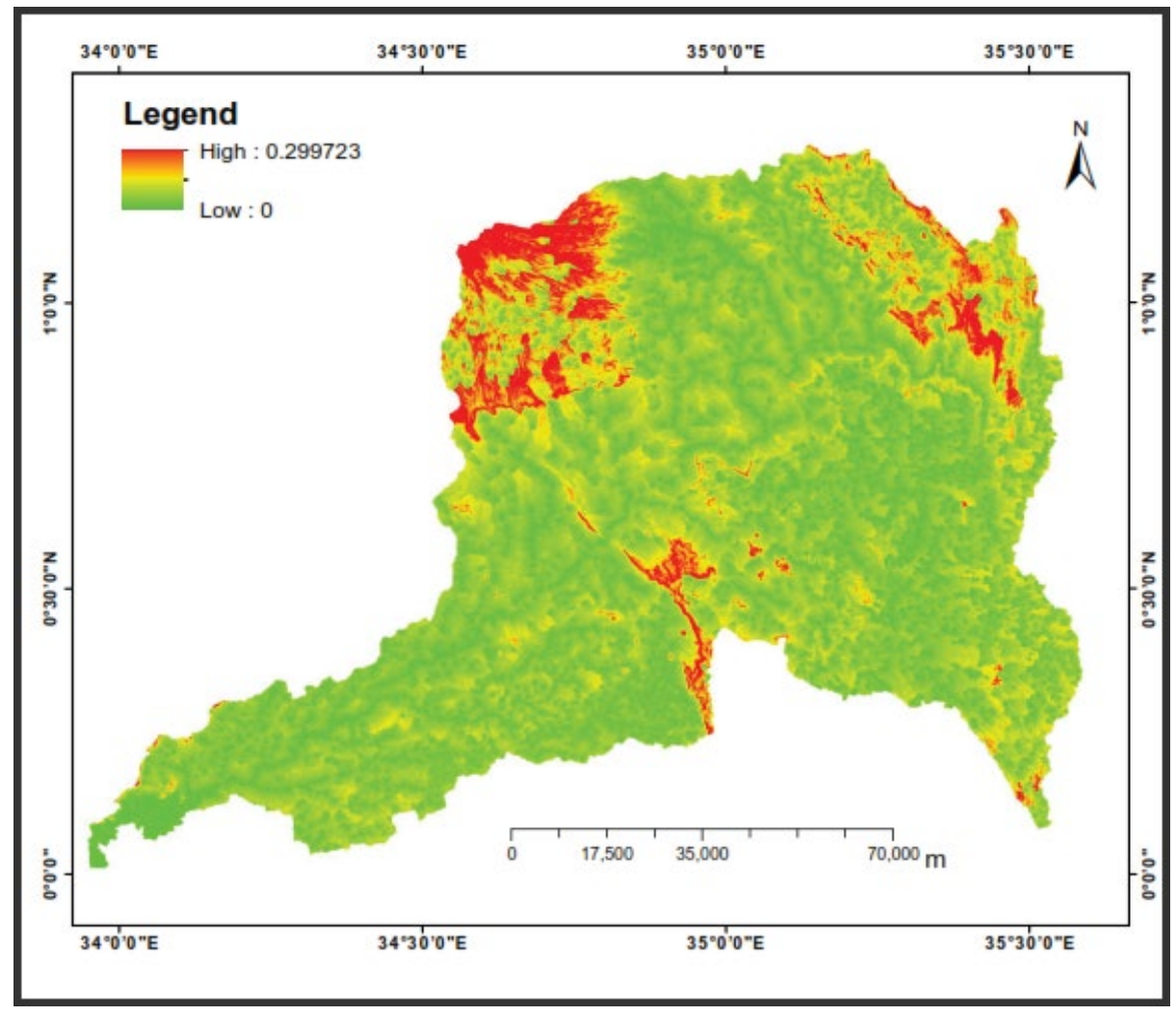

Figure 8: River Nzoia basin slope and slope length (LS) factor. 
where $\alpha, \beta$ : parameters determining the shape of the NDVI-C curve. An $\alpha$-value of 2 and a $\beta$ value of 1 give reasonable results relationship [21]. The C-factor value varied from 0.043 to 0.75 , see Figure 9.

The cover (C) factor represents the effect of cropping and agricultural management practices as well as the effect of ground, tree and grass covers on reducing soil loss. In order to generate the soil erosion hazard map, RUSLE model factors (R, K, LS, and C) were multiplied in Arc GIS 10.1 using the raster calculator. Figure 10 shows the RUSLE model resultant spatial distribution of soil erosion hazard for river Nzoia basin.

The soil loss severity covering high and very high levels are those spatial locations where there is minimal or no canopy cover, with high rainfall intensity and steep slopes. On the erosion hazard map, they indicate areas with high annual average soil loss rates precipitating land degradation. Such areas are considered sediment yield generation sites. For these sites, soil restoration, conservation and management measures are a necessary requirement. However, the low and moderate eroded locations on the map indicate the areas experiencing low annual average soil loss rates. They reflect locations where the vegetation cover could be good enough to provide maximum protection from rainfall impact and thus allowing for minimal surface runoff.

Vegetative cover plays a critical role as erosion is significantly reduced under dense cover [11]. The soil erosion hazard map (at 50\% transparency level) was overlaid with land use map for 2010 to perform more analysis, see Figure 11.

The analysis revealed that annual cropland and the slopes of Mount Elgon, Cherenganyi hills as well as Nandi Escarpments were at a higher risk of erosion. The lowest affected category of land use was forest land. This could be attributed to intensive agricultural activities and deforestation that often lead to removal of vegetation cover and loosening of the soils during cultivation.

Moderate, high and very high erosion risk locations were emphasized for conservation purposes. These regions need appropriate restoration, conservation and management measures on a priority basis. Findings by Githui et al. [22], for river Nzoia basin revealed that removal of vegetation cover leads to increased surface runoff which enhances soil erosion. This is equally in agreement with results in a related study by Kilonzo [23] for upper Mara, Lake Victoria Basin.

\section{Average annual soil loss rate (A)}

Average annual soil loss rate (A) was estimated through multiplication of the RUSLE model factors. The factors' parameters are given in Table 2.

Due to high demographic pressure in the study area, land is fragmented into small units. Within this small units, land use practices employed are almost the same and are distributed throughout river Nzoia basin. Therefore, support practices in the basin are practiced within small pieces of land all over the basin. As a result, in this study, p-factor was assigned a uniform weight of 1.0.

The six parameters were multiplied using raster calculator tool to model the erosion hazard map (Figure 10) and estimated the annual average soil loss rate. The product yielded an average annual soil loss rate of 0.51 and a maximum of $8.84 \mathrm{Mton} \mathrm{ha}^{-1} \mathrm{yr}^{-1}$. Mean annual soil loss was $6.579 \times 10^{5}$ Mtonyr $^{-1}$. This refers to the total mass of soil mobilized within the basin due to water erosion.

\section{Spatial erosion hazard validation}

Classification accuracy assessment of the results was performed

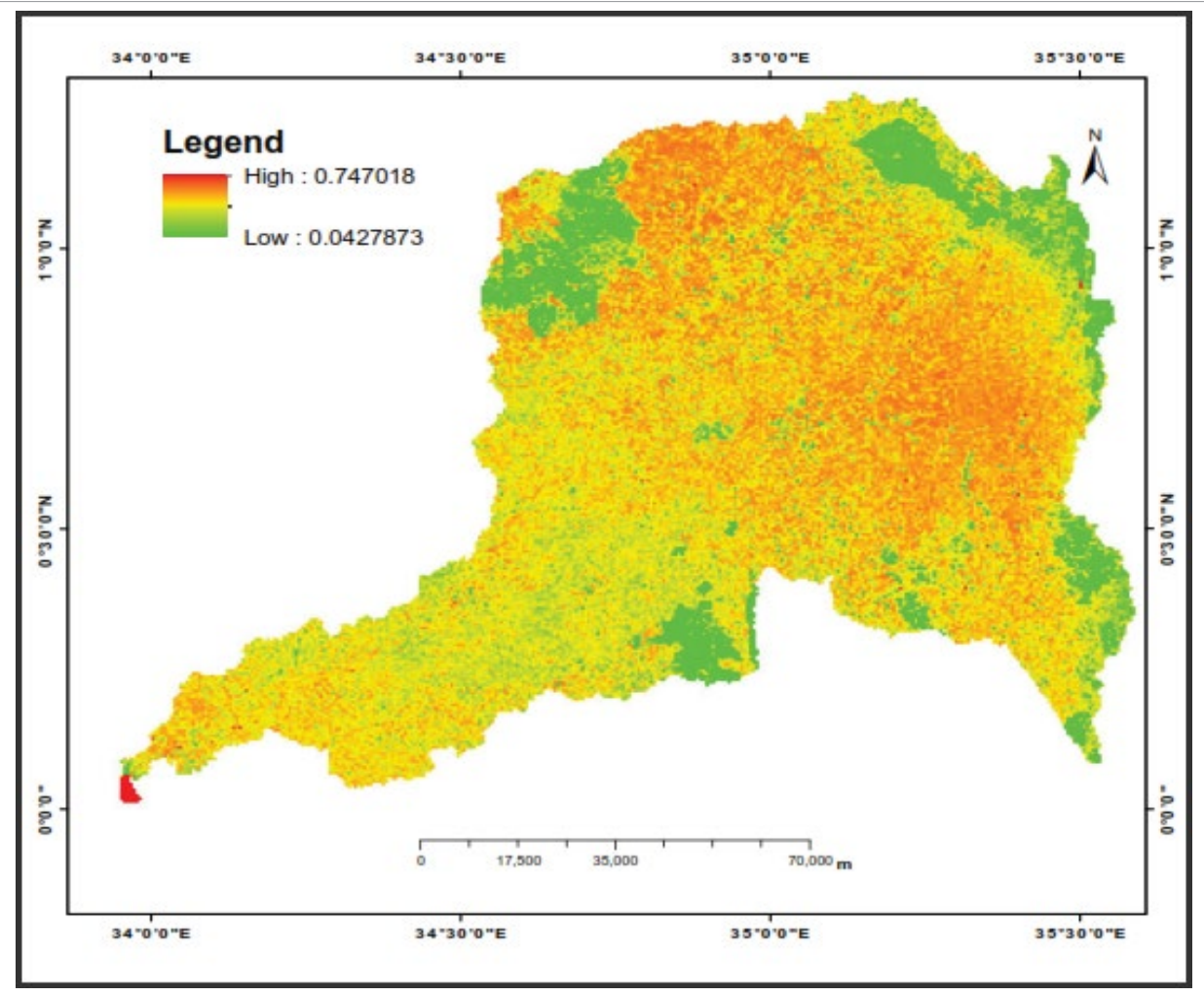

Figure 9: Vegetation cover (C) factor. 


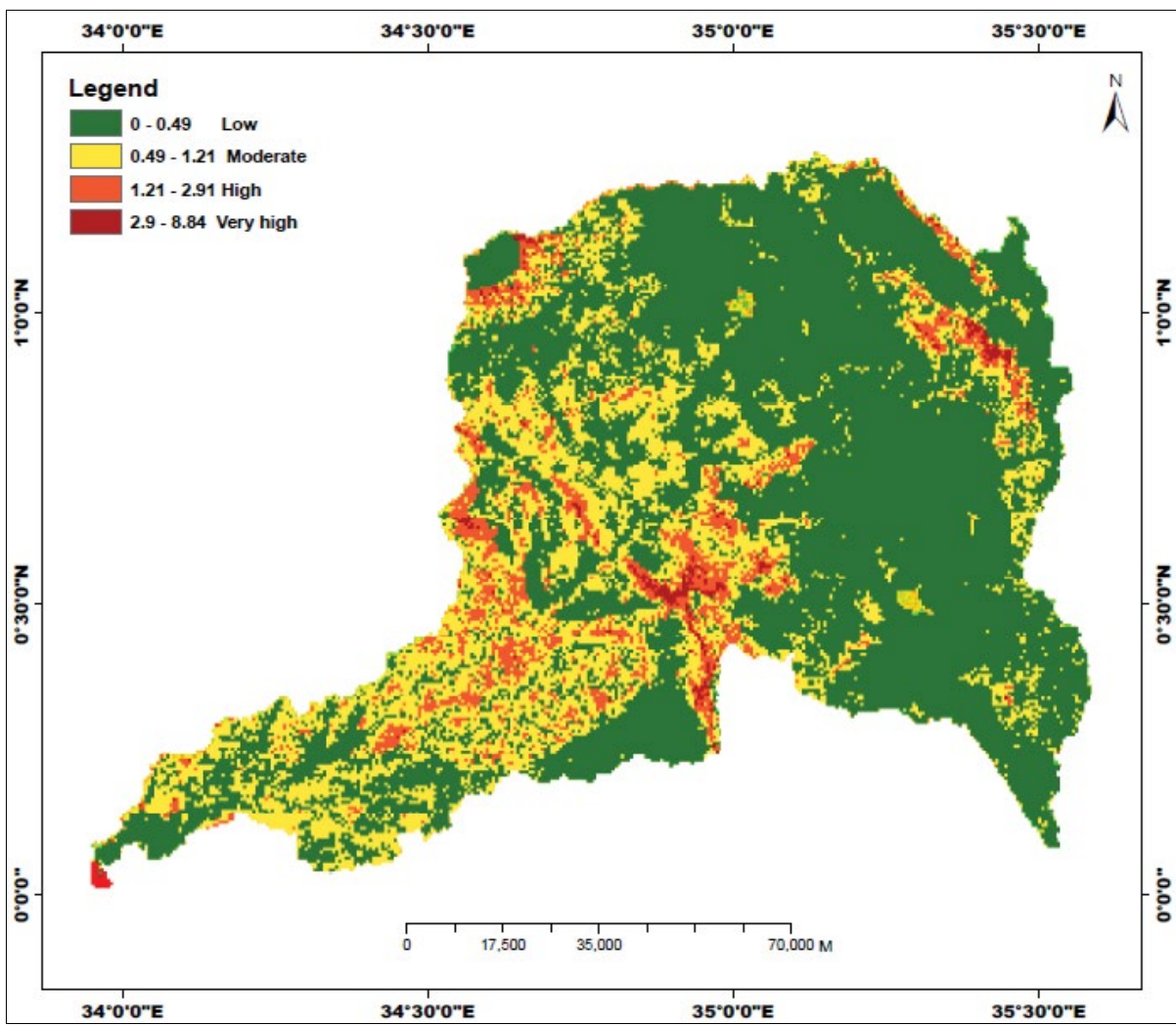

Figure 10: River Nzoia basin soil erosion hazard map.

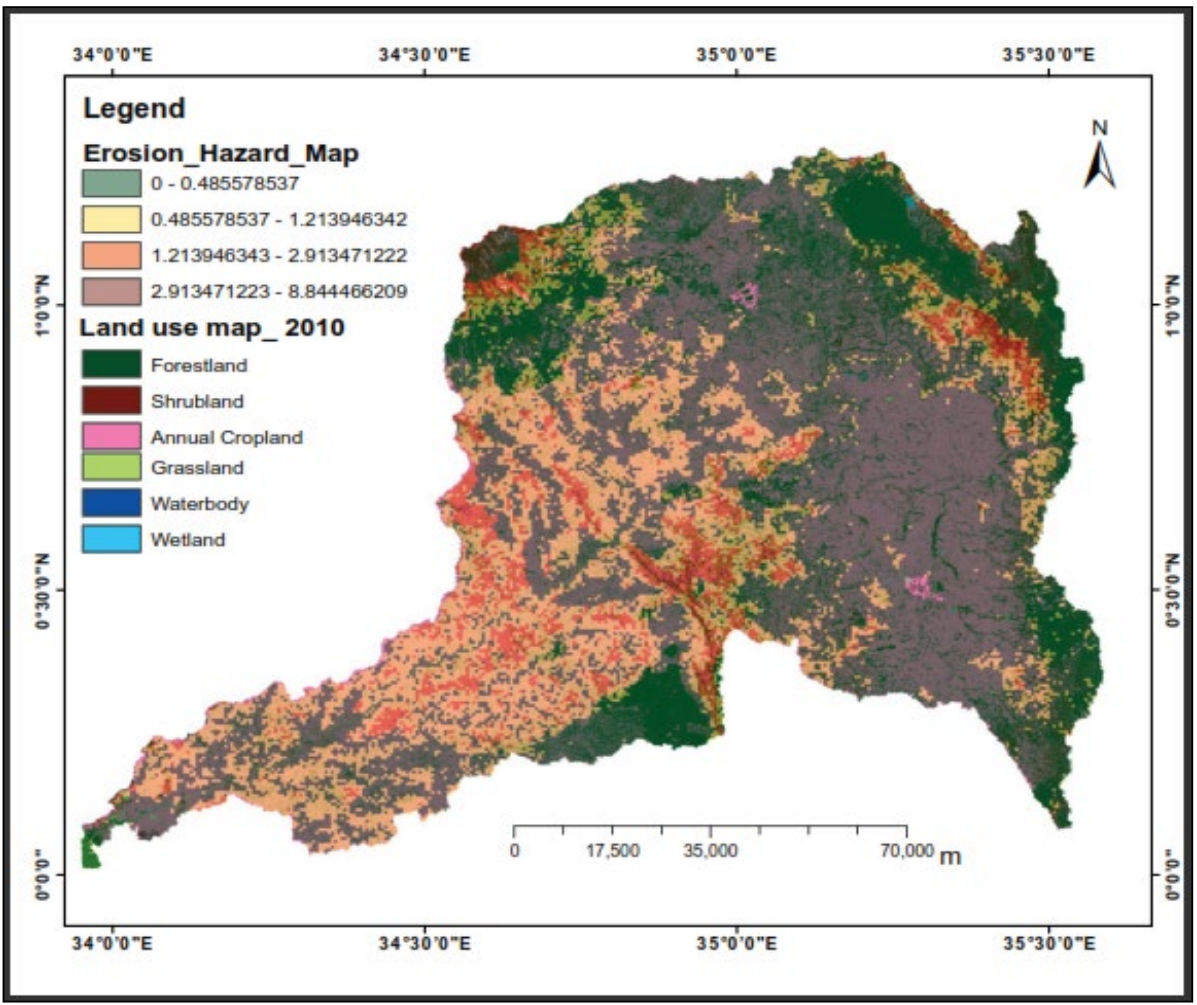

Figure 11: Overlay between soil erosion hazard and 2010 land use map at 50\% transparency level. 


\begin{tabular}{|c|c|c|}
\hline Factor & Range & Mean \\
\hline Rainfall Runoff Erosivity Factor (R) & $339.34-855$ & 574.38 \\
\hline Erodibility Factor (K) & $0-0.305$ & 0.13 \\
\hline Slope Length Factor (L) & $0-0.265$ & 0.02 \\
\hline Slope Steepness Factor (S) & $0-45.93$ & 0.07 \\
\hline Cover Management Factor (C) & $0.011-1.00$ & 0.02 \\
\hline Support Practice Factor (P) & 1 & 0.42 \\
\hline
\end{tabular}

Table 2: RUSSLE model factors and parameters.

based on urban centres' shape file, overlay information from topographic base map, Google Earth, and actual visit of randomly selected sites, see Figures 12-17 respectively.

It can be noted from Figure 3 that regions around Kapenguria, Cherenganyi, Moiben, Iten, Lugari, Kipkaren, Webuye, Chwele, Lukume, Lubao, Butsotso, Mumias and on the slopes of Mt. Elgon including Kaptatelia, Kiminini and Kapsokwony experiencing average annual soil loss rate ranging from 1.21 up to 8.84 tonsha ${ }^{-1} \mathrm{yr}^{-1}$ are the most vulnerable to soil erosion.

This could also be attributed to the effect of urbanization that has resulted into paved surfaces upon which high surface runoff is experienced. The erosion hazard map with $60 \%$ transparency, $65 \%$ contrast and $10 \%$ brightness display levels was also overlaid with online topographic base map, see Figure 13.

The overlay equally reveals that areas neighboring Kapenguria, Kitale, Eldoret and regions covering the slopes of Mt. Elgon, Bungoma and Kakamega are vulnerable to soil erosion. When the erosion map was exported to Google earth and overlaid to perform more analysis, it was observed that highly vulnerable areas to soil erosion include cropland, the peak as well as slopes of Mt Elgon and Cherenganyi Hills, Figures 14 and 15.

Figure 14 confirms the fact that some parts on top of Mt. Elgon are experiencing high levels of soil erosion. Areas under high erosion risk include; Chepkitale, Kitum and Makingeny caves, Mt. Elgon national park extending downwards towards areas neighbouring Chorlim primary school and Saltlick special campsite. This could be associated with forest encroachment in search of land for settlement, agriculture, and urbanization as well as for recreational purposes. The erosion could also be explained from the topographic and ecological dimensions. The area is characterized with steep slopes and receives high amounts of rainfall and thus subject to high surface runoff.

It is also evident that areas spanning southern slopes of Mt. Elgon covering Chwele, Sirisia, Mayanja, Nalondo, Chebukwa, Webuye, Sangalo, among others, are at high soil erosion risk. This could be justified based on the fact that the areas mentioned are a hub of intensive agriculture. The population density in these areas is equally high and thus forest resources have been exploited as a means of livelihood and a source of fuel as well as construction materials.

Figure $11 \mathrm{~b}$ is a visual display of soil erosion hazard in Cherenganyi Hills and some parts of Kakamega County. It can be seen that a stretch covering Iten, Tambachi teachers training college, Kerio valley, Cheptebo, Nyaru and Kimwarer defines an area under very high soil erosion activities. Due to the fertile soils and ample rainfall amounts received in these areas, intensive agriculture is carried out. Topographic aspects such as steep slopes and slope length are a contributory factor to the possible high surface runoff which enhances soil erosion rates.
After soil erosion hot spot areas had been identified from the erosion hazard map, actual visits of randomly selected areas was done to verify the results through actual observation, see Figures 16 and 17.

Kuywa river sub-basin has been under a lot of pressure due to land degradation as well as encroachment into riparian land. Areas sloping from either side of the river banks show evidence of forest land conversion into shrubland, settlements and agricultural land. Removal of the natural forest cover has in turn exposed soils on the steep slopes to high erosion risks from surface runoff leading to sedimentation of river Kuywa, which is a tributary of river Nzoia. River Lwakhakha is a trans-boundary water resource between Kenya and Uganda. This subbasin has since undergone forest degradation due to land use change which may have led to increased river sedimentation and reduced flow rates [11]. Figure 16 shows evidence of human settlement and farming up to the river banks. Similarly, area covering Chepyuk and Kang'anga on the slopes of Mt. Elgon is equally under threat from deforestation and soil erosion, see Figure 17.

As a result of increased demographic pressure, the local community encroached and destroyed forest cover (Chepyuk Phase 3) in search of space for settlement and agricultural activities. The area is under intensive agriculture with Irish potatoes, maize, beans and onions among the main crops grown. Due to continuous tillage of land throughout the year, top soils have been exposed to erosion, particularly during rainfall events. Kang'anga (Nairobi B area) is a reflection of deforested slopes of Mt. Elgon converted into settlement and cropland. It was reported that most of the youth from this area move up the slopes of Mt. Elgon encroaching on the forest for exploitation of natural resources (timber, wood for fuel, construction materials and for hunting) as a livelihood source.

\section{Conclusion}

Soil erosion modeling results showed that river Nzoia basin is experiencing varying erosion rates spatially. The interplay among the RUSLE factors strongly influence average annual soil loss rates. It is perceptible that areas experiencing high soil loss rates are closely linked to annual cropland, deforested and high elevation point areas. Low rates of soil loss are attributable to soil conservation practices and protected areas including game parks. Therefore, there is a close coupling between soil loss and land use category in river Nzoia basin.

\section{Recommendation}

Assessment of sediment produced by gully erosion and mass movement should be done to determine the effective soil erosion loss experienced in river Nzoia basin. Soil conservation measures should mainly target erosion hotspots to minimize soil losses. Sediment Delivery Ratio (SDR) should be determined based on topographic factors (Slope and slope length) to validate SDR due to area based methods used in this study to estimate sediment yield. Sustainable land 
Citation: Moses AN (2017) GIS-RUSLE Interphase Modelling of Soil Erosion Hazard and Estimation of Sediment Yield for River Nzoia Basin in Kenya. J Remote Sensing \& GIS 6: 205. doi: 10.4172/2469-4134.1000205

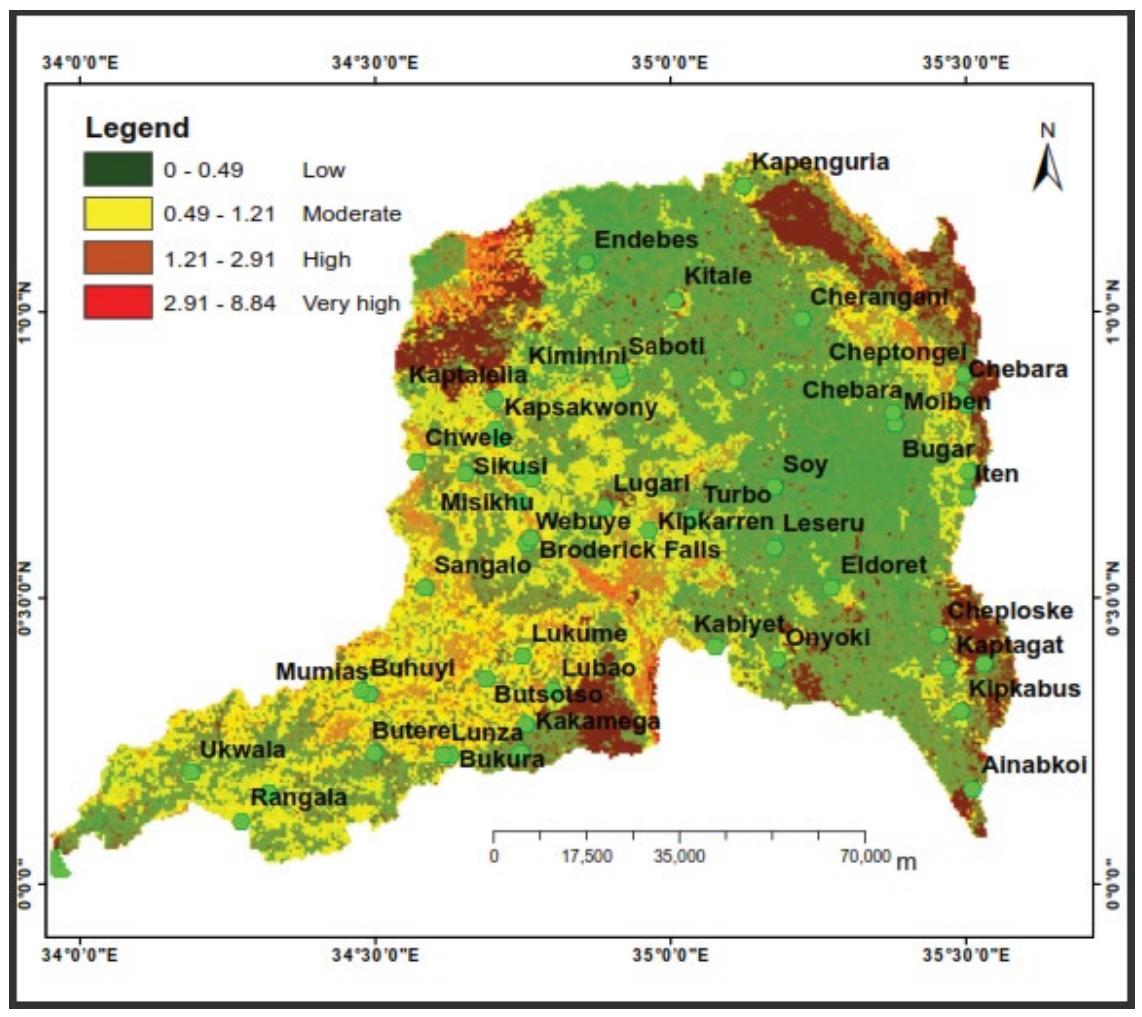

Figure 12: Overlay between erosion hazard map and main urban centres in river Nzoia basin.

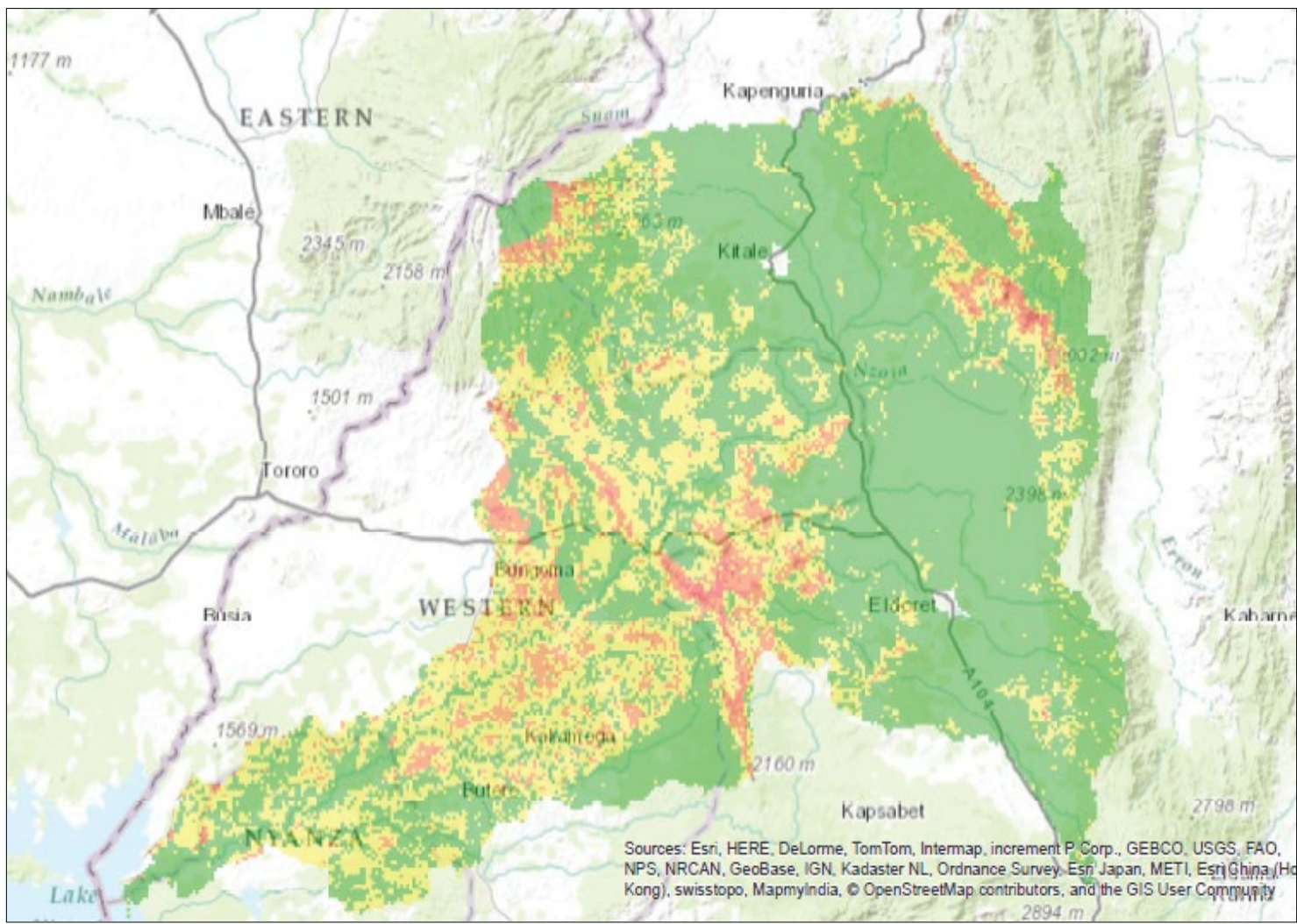

Figure 13: Overlay of erosion hazard map with the base map of the study area. 
Citation: Moses AN (2017) GIS-RUSLE Interphase Modelling of Soil Erosion Hazard and Estimation of Sediment Yield for River Nzoia Basin in Kenya. J Remote Sensing \& GIS 6: 205. doi: 10.4172/2469-4134.1000205

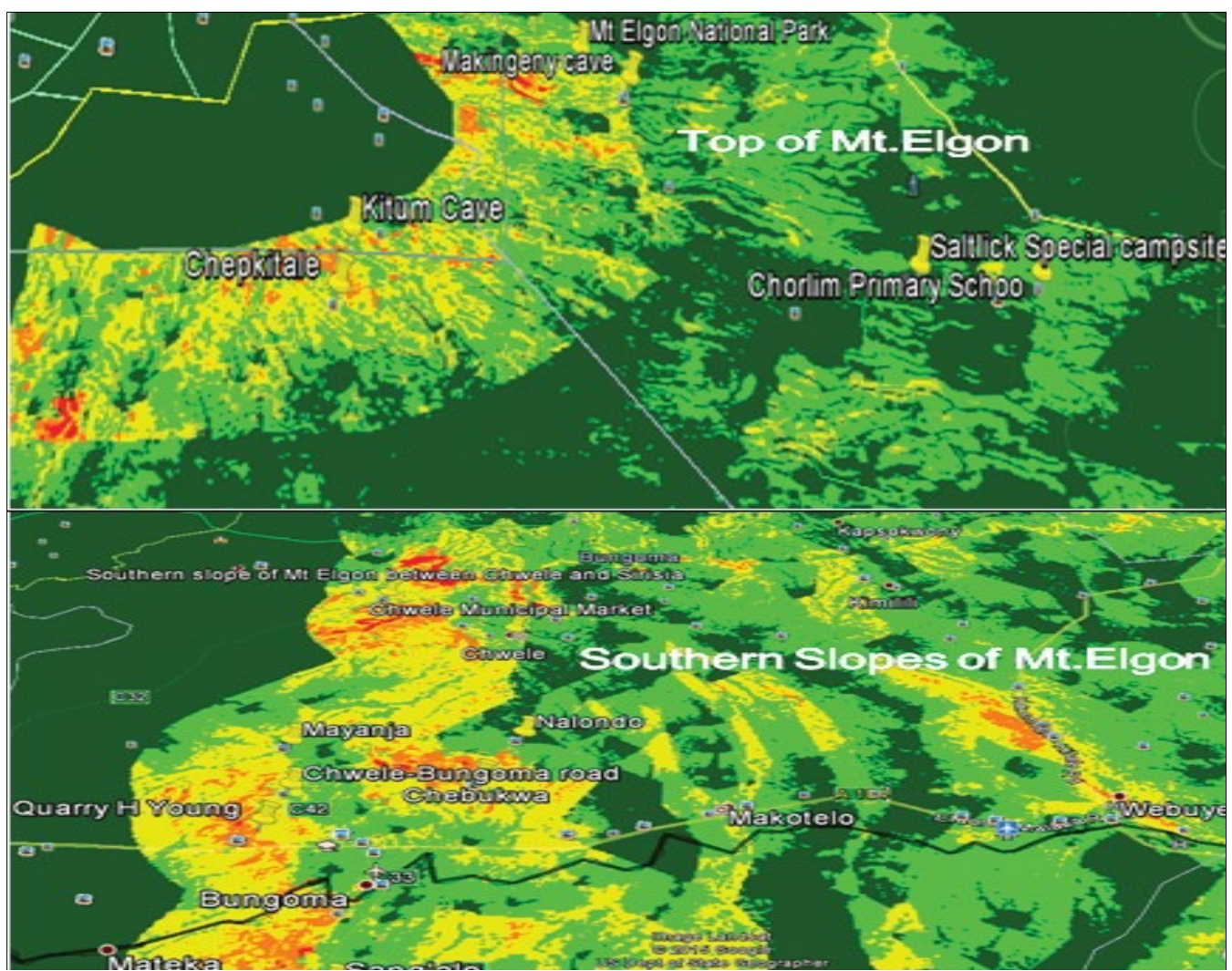

Figure 14: Google Earth map showing erosion on top of Mt. Elgon and its southern slopes.

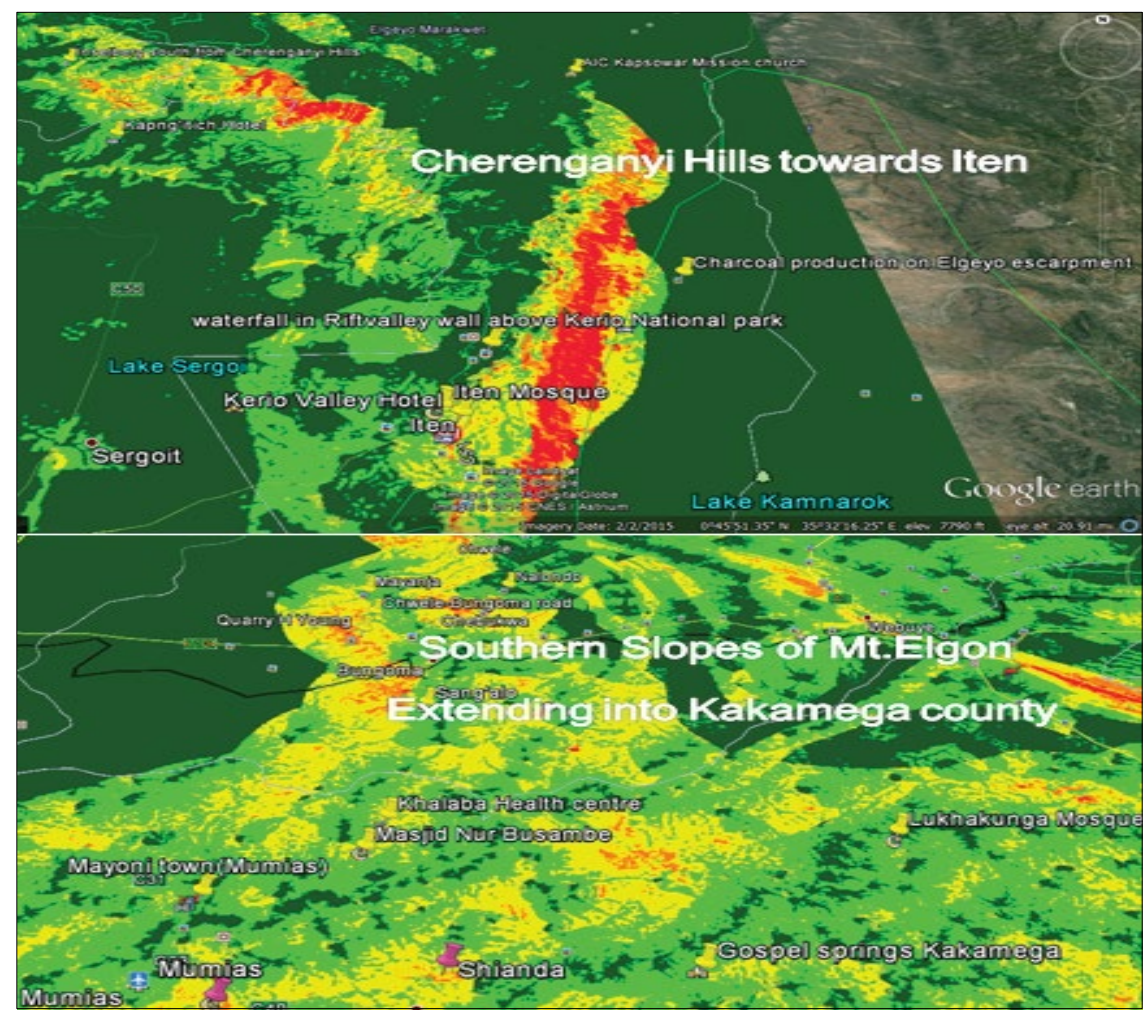

Figure 15: Google Earth map showing erosion in Cherenganyi Hills and Kakamega County. 


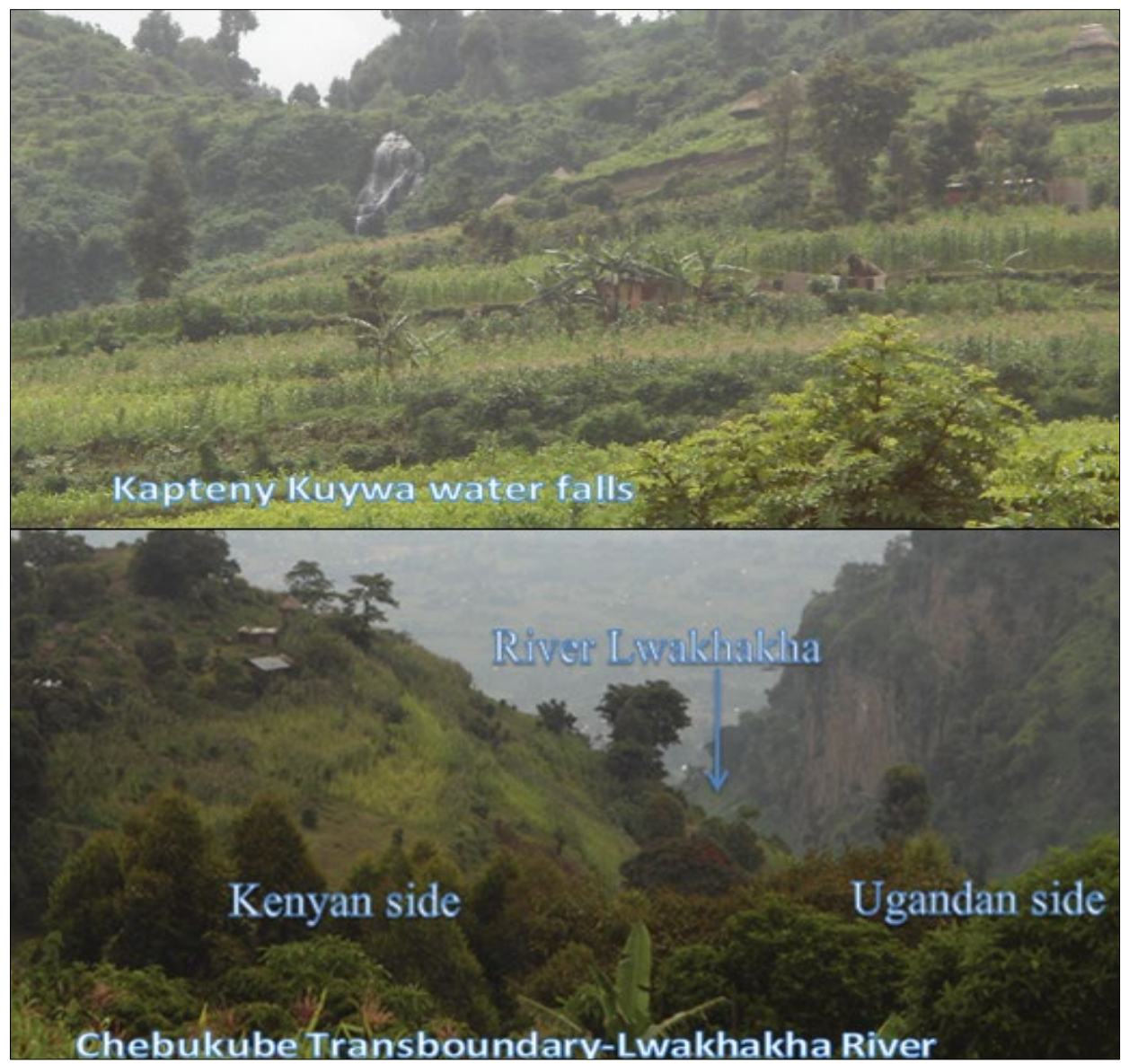

Figure 16: Degraded Kuywa and Lwakhakha river sub-basins.
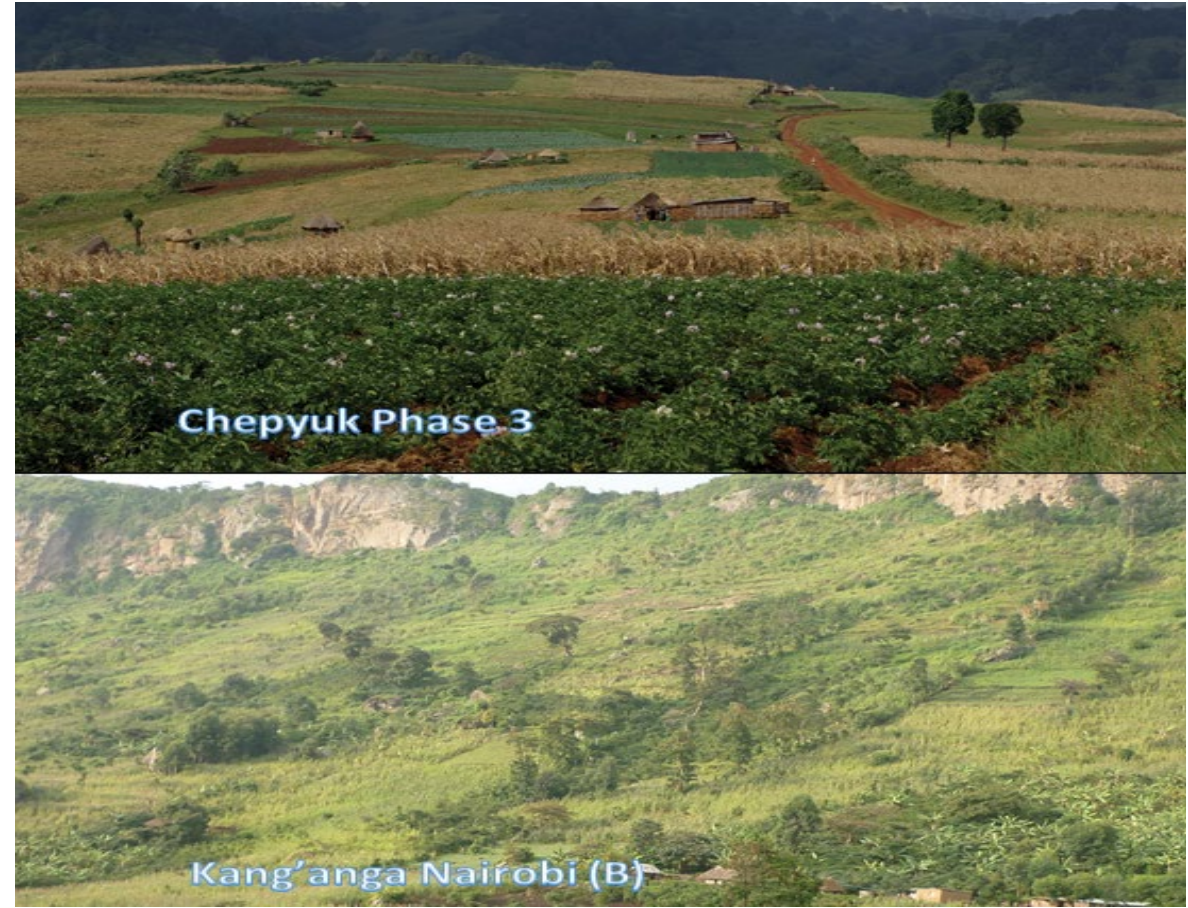

Figure 17: Degraded Kuywa and Lwakhakha river sub-basins. 
Citation: Moses AN (2017) GIS-RUSLE Interphase Modelling of Soil Erosion Hazard and Estimation of Sediment Yield for River Nzoia Basin in Kenya. J Remote Sensing \& GIS 6: 205. doi: 10.4172/2469-4134.1000205

use practices should be embraced to support conservation programmes to mitigate soil erosion, prevent sedimentation as well as reduce sediment yield in the river channel.

\section{References}

1. Ritchie JC, Walling DE, Peters J (2003) Application of geographic information systems and remote sensing for quantifying patterns of erosion and water quality. Hydrological Processes 17: 885-886.

2. Rooseboom A, Verster E, Zietsman HL, Lotriet HH (1992) The development of the new sediment yield map of southern Africa. Water Research Comm Report, p: 92.

3. Manoj KJ, Surendra KM, Shah RB (2010) Estimation of sediment yield and areas vulnerable to soil erosion and deposition in a Himalayan watershed using GIS. Current Science 98: 213-221.

4. Jaramillo $F$ (2007) Estimating and modelling soil loss and sediment yield in the Maracas-St. Joseph River Catchment with empirical models (RUSLE and MUSLE) and a physically based model (Erosion 3D).

5. Catari G (2010) Assessment of uncertainties of soil erosion and sediment yield estimates at two spatial scales in the upper llobregat basin (SE Pyreness, Spain).

6. Belay T (2002) Land cover/land use change in the Derekolli Catchment, South Wolo Zone of Amhara Region, Ethiopia. Eastern Africa Social Science Research Review 18: 1-20.

7. Kithiia SM, Ongwenyi GS (1997) Some problems of water quality degradation in the Nairobi River sub-basins in Kenya. IAHS Publication 243: 121-127.

8. Kundu PM, China Samuel S, Wambua RM (2009) Quantifying Land Cove and Land use change by Remote sensing and GIS Techniques in River Njoro Catchment Kenya. Int J Disaster Manag Risk Reduct 2: 35-43.

9. Sangale FO, Okungu J, Opango $P$ (2001) Variation of flow of water fromRivers Nzoia, Yala and Sio ito L. Victoria Regional Scientific Conference Held at Kisumu Kenya.

10. Okungu J, Opango P (2001) Pollution loads into Lake Victoria from the Kenyan catchment. Knowledge and experiences gained from managing the Lake Victoria ecosystem. Dar es Salaam: Regional Secretariat, Lake Victoria Environmental Management Project (LVEMP) pp: 90-108.
11. Akali NM, Oteng'i SBB, Masibayi EN, Mokua FA, Maloba J (2015) GIS-based Modeling of Land Use Dynamics in River Nzoia Basin, Kenya. Global Journa of Engineering Science and Research Management 2: 88-104.

12. Mokua FO (2009) Application of GIS and Remote Sensing in the Estimation of Revised Universal Soil Loss Equation (RUSLE) K, C and P Factors for Kapingazi Catchment Soil Erosion Assessment. Msc Research Project Report Department of Geomatic Engineering and Geospatial Information Systems. Jomo Kenyatta University of Agriculture and Technology.

13. Bayramin I, Dengiz O, Başkan O, Parlak M (2003) Soil Erosion Risk Assessment with ICONA Model, Case Study: Beypazarı Area. Turkish Journal of Agriculture and Forestry 27: 105-116.

14. Watson HK, Ramokgopa R (1996) The distribution of erosion in the Mfoloz drainage basin implications for sediment yield control. Erosion and Sediment Yield: Global and Regional. Accessed on $13^{\text {th }}$ May 2014.

15. Mhangara $P$ (2011) Land use/cover change modelling and land degradation assessment in the Keiskamma catchment using remote sensing and GIS. Accessed on $12^{\text {th }}$ July 2014.

16. Wischmeier W, Smith DP (1978) Predicting Rainfall Erosion Losses- A Guide to conservation planning. Pp: 537.

17. Walling DE (1983) The sediment delivery problem. J Hydrology 65: 209-237.

18. Piyawat W, Singh MB (2014) Principal Component and Multiple Regression Analyses for the Estimation of Suspended Sediment Yield in Ungauged Basins of Northern Thailand. Water 6: 2412-2435.

19. World Meteorological Organization (WMO) (2004) Strategy for Flood Management for Lake Victoria Catchment, Kenya.

20. Elena D (2011) Modelling alternative agricultural scenarios using RUSLE and GIS to determine erosion risk in the Chippewa River Watershed. Minnesota.

21. Ioannis Z, Gitas KD, Chara M, George N, Christos G (2009) Multi-Temporal Soil Erosion Risk Assessment in N. Chalkidiki Using a Modified USLE Raster Model. EARSeL eProceedings 8: 40-52.

22. Githui F, Gitau W, Mutua F, Bauwens W (2009) Climate change impact on SWAT simulated streamflow in western Kenya. International Journal of Climatology 29: $1823-1834$.

23. Kilonzo NF (2014) Assessing the Impacts of Environmental Changes on the Water Resources of the Upper Mara, Lake Victoria Basin. Netherlands: CRC Press/Balkema EH Leiden. 